\title{
Stimulus Gambar: Sebuah Kajian pada Instrumen Minat Vokasional
}

\author{
Firmanto Adi Nurcahyo', Saifuddin Azwar', Wisjnu Martani ${ }^{3}$, \& Badrun Kartowagiran ${ }^{4}$ \\ 1,2,3Fakultas Psikologi Universitas Gadjah Mada \\ ${ }^{4}$ Program Pascasarjana Universitas Negeri Yogyakarta
}

\begin{abstract}
Vocational interest instruments are mostly based on verbal stimuli which require subjects' reading ability. Another form of stimuli is needed for the populations that have reading difficulty. This article offers an explanation of using pictures as stimuli in the development of an instrument to assess adolescents' vocational interest as well as the steps in developing pictorial stimuli. Compared to verbal, pictorial stimuli are closer to real life and have supporting information related to the activities. However, some limitation in using pictorial stimuli such as difficulty in describing hardly observable behavior and ambiguity of the pictures that can affect individual interpretation need to be considered.
\end{abstract}

Keywords: instrument development; pictorial stimuli; vocational interest

\section{Pengantar}

Format aitem merupakan bentuk aitem yang digunakan pengembang instrumen psikologi sebagai usaha untuk memperoleh respon dari responden. Pemilihan format aitem menjadi bagian awal dalam penyusunan suatu instrumen. Penjelasan mengenai format aitem umumnya dimasukkan sebagai bagian dari kisi-kisi instrumen.

Format aitem yang umum dipakai oleh pengembang instrumen psikologi adalah bentuk pernyataan dan pertanyaan (Azwar, 2015). Kalimat deklaratif biasa digunakan pada bentuk format pernyataan, sedangkan kalimat tanya dipakai pada bentuk format pertanyaan. Pada kedua bentuk format tersebut tidak menutup kemungkinan digunakannya gambar sebagai stimulus yang mendahului suatu pernyataan atau pertanyaan.

\footnotetext{
${ }^{1}$ Korespondensi artikel ini dapat dilakukan melalui: firmanto.adi.n@mail.ugm.ac.id
}

Penggunaan gambar sebagai stimulus dalam pengembangan instrumen psikologi menjadi alternatif di tengah maraknya penggunaan kata atau kalimat sebagai stimulus. Stimulus gambar memiliki kelebihan dibandingkan stimulus berupa kata atau kalimat. Namun demikian, penggunaan stimulus gambar tentunya tak lepas dari berbagai kelemahan.

Tulisan ini bertujuan untuk mendiskusikan penggunaan stimulus gambar sebagai alternatif dari stimulus pernyataan dalam pengembangan instrumen psikologi. Instrumen psikologi dalam tulisan ini difokuskan pada instrumen minat vokasional. Ini dikarenakan oleh teori minat, yang umumnya membagi minat menjadi beberapa tipe, memberikan deskripsi yang jelas untuk setiap tipe minat. Hal ini memungkinkan pengembang instrumen untuk mewujudkan deskripsi masing-masing minat dalam bentuk gambar. Sumbangan pemikiran mengenai langkah-langkah mengembangkan gambar sebagai stimulus 
dalam penyusunan instrumen minat vokasional disuguhkan pada akhir tulisan.

\section{Pembahasan}

\section{Sekelumit tentang Minat}

Pembahasan dalam tulisan ini didahului dengan sedikit paparan mengenai minat. Minat memiliki pengaruh dalam pemilihan suatu aktivitas yang dilakukan oleh individu dalam kehidupan keseharian. Jika seseorang memiliki waktu luang dalam suatu hari, maka minat berpengaruh terhadap aktivitas apa yang dipilih individu tersebut dalam mengisi waktu luangnya. Minat juga berpengaruh pada keputusankeputusan penting dalam kehidupan individu misalnya dalam pemilihan pekerjaan.

Minat vokasional merupakan istilah yang sering dipakai untuk menggambarkan minat individu yang mengarah pada suatu pekerjaan. Van Iddekinge, Putka, \& Campbell (2011) mendefinisikan minat vokasional sebagai perbedaan antar individu yang berpengaruh terhadap perilaku memilih suatu aktivitas dan lingkungan kerja. Minat vokasional cenderung menetap dalam diri individu dan memotivasi individu untuk melakukan perilaku yang mereka sukai (Low, Yoon, Roberts, \& Rounds, 2005).

Beragam konstrak minat vokasional telah disusun oleh para ahli seperti misalnya Strong, Kuder, serta Holland. Pengembangan konstrak Strong dan Kuder menekankan pada data empiris yakni konsistensi dalam data (Hansen, 2011). Kuder misalnya menentukan minat berdasarkan kesamaan respon individu-individu dalam suatu pekerjaan. Jika para seniman memiliki minat terhadap sepak bola, maka diartikan bahwa minat terhadap sepak bola terkait dengan seni. Di sisi lain, konstrak minat Holland didasarkan pada dasar teori yang kuat (Hansen, 2011). Teori tersebut mendeskripsikan dengan detail karakteristik dari masing-masing minat serta menjelaskan hubungan antar minat.

Holland meyakini bahwa individu dapat dikategorisasikan sebagai salah satu dari tipe minat Realistic, Investigative, Artistic, Social, Enterprising, atau Conventional (Foutch, McHugh, Bertoch, \& Reardon, 2014; Holland, 1985). Keenam tipe minat tersebut umum disingkat RIASEC. Masing-masing tipe minat tersebut memiliki karakteristik tersendiri yang membedakan satu minat dengan yang lain. Individu tipe Realistic cederung memilih aktivitasaktivitas yang eksplisit terhadap objek, peralatan, atau mesin; individu tipe Investigative lebih menyukai aktivitasaktivitas obervasional atau penyelidikan terhadap suatu fenomena; individu tipe Artistic lebih memilih aktivitas-aktivitas yang bebas yang bertujuan untuk menciptakan produk seni; individu tipe Social lebih memiliki aktivitas-aktivitas melatih, mengembangkan, menyembuhkan, atau mengajar orang lain; individu tipe Enterprising memilih aktivitas-aktivitas yang melibatkan orang lain untuk mencapai tujuan organisasi atau keuntungan ekonomis; individu tipe Conventional lebih menyukai aktivitas-aktivitas menggunakan data secara sistematis seperti menyimpan, mengarsip, serta mengorganisasi data (Holland, 1985).

Instrumen Minat Vokasional dengan Stimulus Kata/Kalimat

Untuk mengetahui minat vokasional individu, pengukuran minat perlu dilakukan. Pengukuran minat vokasional ditujukan untuk mengidentifikasi minat vokasional individu sebagai usaha memfasilitasi dalam pemilihan karir (Gregory, 2000). Hasil pengukuran minat vokasional dipergunakan konselor dalam mengarahkan individu pada pekerjaan tertentu (Dozier, Sampson, 
Lenz, Peterson, \& Reardon, 2015; Miller, 2002).

Pengukuran minat banyak dilakukan melalui instrumen minat vokasional. Instrumen-instrumen minat yang ada umumnya dikembangkan berdasarkan pada suatu teori. Konstrak teoretis Holland misalnya menjadi dasar penyusunan Self Directed Search (SDS) yang dikembangkan pada tahun 1970. Instrumen ini diakui banyak dipakai dalam pengukuran minat vokasional (Poitras, Guay, \& Ratelle, 2012).

Format aitem SDS berupa pernyataan yang menunjukkan aktivitas, kompetensi, serta pekerjaan (Holland, 1985). Setiap pernyataan diwujudkan dalam bentuk kata, gabungan kata, atau sebuah kalimat. Aitem berupa kata terlihat pada aitem pekerjaan seperti "Biologist", "Chemist", dan "Physicist" yang menunjukkan pekerjaan Investigative. Beberapa aitem pekerjaan terdiri atas gabungan kata seperti misalnya "Speech Therapist" dan "Marriage Counselor" yang menunjukkan pekerjaan minat sosial. Aitem-aitem aktivitas juga diwujudkan dalam gabungan kata. Ini terlihat seperti pada aitem aktivitas Realistic yakni "fix electrical things", "repair cars", "fix mechanical things", dan "build things with wood". Aitemaitem yang menunjukkan kompetensi diwujudkan dalam bentuk kalimat. Aitem kompetensi untuk minat Enterprising misalnya "I can supervise the work of others", "I am a good sales person", dan "I have organize a club, group, or gang".

\section{Strong Interest Inventory} merupakan instrumen minat yang dinilai mampu mengoperasionalisasikan model Holland dan banyak dipakai dalam penelitian lintas budaya (Goh, Lee, \& Yu, 2004). Selama bertahun-tahun, SII mengalami peningkatan pemakaian di negara berbahasa Inggris maupun non-Inggris. SII terdiri atas 317 aitem pernyataan yang terbagi dalam 8 bagian termasuk di dalam- nya adalah nama pekerjaan, mata pelajaran sekolah, serta aktivitas (Goh \& Yu, 2001). Aitem-aitem SII diwujudkan dalam bentuk gabungan kata. Contoh aitem pekerjaan dalam SII adalah "athletic director", "cashier in bank", "civic service employee", serta "employment manager". Contoh aitem yang menunjukkan aktivitas adalah "acting", "English compotition/writing", serta "doing your own laundry work".

Personal Globe Inventory (PGI) juga merupakan instrumen minat berbasis teori Holland. PGI dikembangkan oleh Tracey (2002) dengan format aitem pernyataan yang terdiri atas dua bagian. Bagian pertama terdiri atas 108 nama pekerjaan seperti misalnya "financial analyst", "physicist", "airplane mechanic", "hotel manager", "sculptor", serta "school counselor". Bagian kedua terdiri atas 113 aitem aktivitas seperti misalnya "sell goods to others", "write poetry", "prepare financial reports", "write a scientific article", serta "install electrical wiring".

Verb Interest Test (VIT) dikembangkan oleh Wetzel, Hell, \& Passler (2012) berdasarkan teori Holland. Aitem VIT berupa pernyataan yang diwujudkan dalam bentuk kata kerja yang berjumlah 113 aitem. Ini didasari oleh pandangan bahwa kata kerja merupakan suatu alternatif yang menjanjikan dalam mendeskripsikan aktivitas-aktivitas pekerjaan karena tidak bergantung pada konteks, hemat waktu, dan dapat diterapkan pada responden dengan semua latar belakang tingkat pendidikan. Contoh aitem-aitem minat Realistic pada VIT adalah "to build", "to carve", "to repair", dan "to drill", sedangkan contoh aitem-aitem minat Enterprising adalah "to bargain", "to convince", "to direct", serta "to negotiate".

Beberapa instrumen minat vokasional juga dikembangkan di Indonesia. Pengembangan instrumen tersebut dilakukan baik 
melalui adaptasi terhadap instrumen yang sudah ada maupun menyusun instrumen yang baru. Adaptasi terhadap Self Directed Search Form Career Planning (SDS Form CP) dilakukan oleh Ratri (2016). SDS Form CP secara khusus dirancang untuk profesional dan orang dewasa yang sedang berada dalam masa transisi. Adaptasi instrumen dilakukan dengan menerjemahkan dan mengujicobakan aitem-aitem SDS Form CP. Aitem-aitem SDS Form CP berupa pernyataan-pernyataan yang terdiri atas 3 bagian yakni aktivitas, kompetensi, dan pekerjaan. Contoh aitem pekerjaan hasil adaptasi adalah "ahli pembuatan mebel", "ahli pengelasan", "insinyur", "konselor keluarga", serta "petugas perpustakaan".

Instrumen minat vokasional baru dikembangkan oleh Artosandi (2016) dengan nama Skala Minat Vokasional. Pengembangan instrumen tersebut didasarkan pada teori Holland. Skala Minat Vokasional memiliki format aitem berupa kalimatkalimat pernyataan yang terdiri atas 24 aitem. Contoh aitem yang menunjukkan minat Investigative adalah "Saya senang halhal yang bersifat ilmiah" dan "Saya mampu menggunakan mikroskop". Contoh aitem yang menunjukkan minat sosial adalah "Saya adalah seorang yang sangat peduli terhadap orang lain" serta "Saya dapat melakukan aktivitas mengungkapkan perasaan dengan jelas".

Aitem dalam instrumen minat juga dapat diwujudkan dalam bentuk cerita atau suatu situasi. Hal ini misalnya ditemukan pada instrumen minat yang dikembangkan Nurcahyo \& Azwar (2008). Pada instrumen tersebut, aitem diwujudkan dalam bentuk situasi yang sering dijumpai dalam kehidupan keseharian yang diikuti enam pilihan jawaban yang merepresentasikan masingmasing karakteristik minat Holland. Contoh aitem tersebut adalah "Saya merasa senang jika bisa melewatkan liburan dengan mengikuti pelatihan/kursus mengenai": a) menyetir mobil; b) sistem jaringan internet; c) pembuatan karya seni (lukisan, batik, dsb.); d) antisipasi penyakit menular; e) kiat-kiat membuka usaha; dan f). kiat-kiat penulisan lamaran kerja/ laporan penting.

\section{Kelemahan Stimulus Kalimat}

Terdapat beberapa kelemahan instrumen minat dengan stimulus berupa kata atau kalimat. Kelemahan stimulus berupa kata atau kalimat adalah dalam hal kebergantungannya terhadap kemampuan membaca dari responden (Boerchi \& Magnano, 2015; Enke, 2009; Šverko, Babarović, \& Međugorac, 2014). Hal ini membuat instrumen tersebut hanya cocok untuk individu yang memiliki kemampuan membaca dengan baik.

Kendala inventori minat dengan stimulus berupa kata terkait dengan aitem yang berupa nama pekerjaan. Hal ini dicontohkan dengan aitem pekerjaan "farmer" dan "astronomer" pada SDS yang tidak dikenal di Hong Kong (Leung \& Hou, 2001). Ini dikarenakan urbanisasi telah memusnahkan aktivitas pertanian di Hong Kong, serta tidak ditemui program studi astronomi di Hong Kong. Aitem-aitem pekerjaan yakni juvenile delinquency expert, locomotive engineer, bank examiner, dan social science researcher juga tidak dipahami oleh subjek di Hong Kong (Ting, 2007).

Penerjemahan aitem dapat menjadi permasalahan pada proses adaptasi instrumen minat. Goh dan Yu (2001) mengalami kendala dalam penerjemahan aitem SII dari bahasa Inggris ke bahasa Cina. Ini misalnya karena tidak ditemuinya kata dalam bahasa Cina yang ekuivalen dengan aitem "athletic director". Tanggung jawab seorang "athletic director" yang dikenal di Amerika Serikat dilakukan oleh "coach" di Cina. Hal ini membuat penerjemahan literal terhadap aitem tersebut 
menjadi kurang tepat. Contoh lain terdapat pada aitem pekerjaan yaitu "bank teller" dan "cashier in bank". Kedua aitem tersebut jika diterjemahkan ke dalam bahasa Cina akan menghasilkan nama pekerjaan yang sama yang ekuivalen dengan "bank teller" di Amerika Serikat.

\section{Instrumen Minat Vokasional dengan Stimulus} Gambar

Stimulus dalam bentuk gambar digunakan oleh Geist (1959) dalam menyusun inventori minat vokasional dengan nama Geist Picture Interest Inventory (GPII). Awalnya, Geist menggunakan foto sebagai stimulus dalam inventori yang dikembangkannya tersebut. Namun demikian, Geist mendapati bahwa kebanyakan foto bersifat ambigu. Oleh karena itu Geist memilih untuk menggunakan gambar sebagai stimulus. Menurutnya, penggunaan stimulus berupa gambar lebih dapat menggambarkan karakteristik suatu tipe minat dibandingkan dengan foto (Geist, 1959).

Stimulus gambar dalam GPII mendeskripsikan figur yang sedang melakukan suatu aktivitas pekerjaan. Geist (1959) mengungkapkan bahwa gambar-gambar tersebut mencerminkan pekerjaan-pekerjaan yang ada di Amerika Serikat. GPII terdiri atas 44 aitem, setiap aitem terdiri atas tiga gambar. Subjek diminta untuk memilih gambar yang mencerminkan aktivitas yang paling mereka sukai di antara ketiga gambar tersebut.

Format aitem berupa gambar juga digunakan Becker (1973) dalam mengembangkan Reading-Free Vocational Interest Inventory (R-FVII). Inventori ini dirancang bagi individu yang mengalami retardasi mental namun masih bisa dididik. R-FVII terbagi menjadi dua versi, inventori lakilaki yang terdiri atas gambar-gambar dengan figur laki-laki dan inventori perempuan yang terdiri atas gambargambar dengan figur perempuan. Setiap aitem pada R-FVII terdiri atas 3 pilihan gambar. Dari ketiga pilihan gambar, subjek diminta untuk memilih satu gambar yang paling disukainya. Gambar 1 menunjukkan contoh aitem R-FVII.

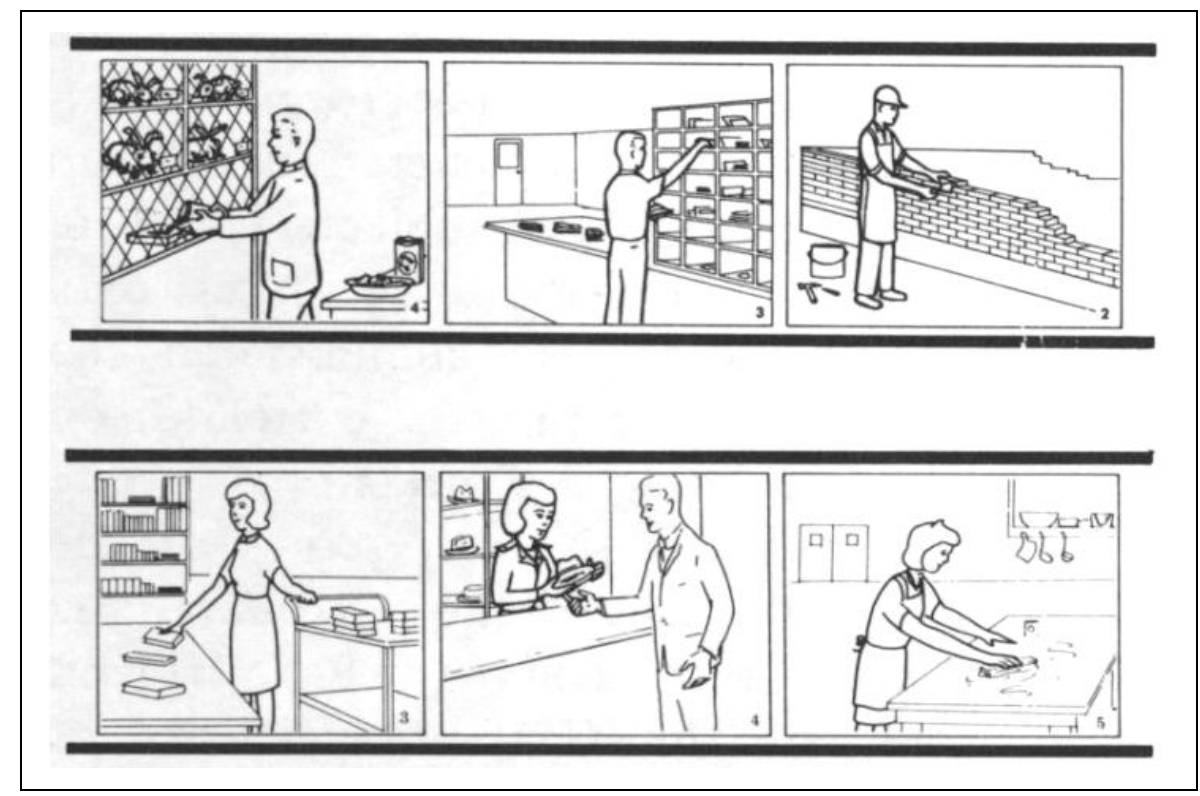

Gambar 1. Contoh aitem R-FVII laki-laki dan perempuan yang terdiri atas 3 gambar. Diambil dari “Vocational choice: An inventory approach. Education and Training of the Mentally Retarded" oleh R. L. Becker, 1973, Education and Training of the Mentally Retarded, 8,h. 129. 


\section{STIMULUS GAMBAR: INSTRUMEN MINAT VOKASIONAL}

Pengembangan instrumen minat dengan stimulus berupa gambar juga dilakukan oleh Enke (2009) dengan mewujudkan 48 aitem pernyataan dalam Personal Globe Inventory (PGI) menjadi bentuk gambar. Setiap aitem diwujudkan dalam dua buah gambar yang menampakkan figur dengan jenis kelamin laki-laki dan perempuan yang sedang melakukan suatu aktivitas. Gambar dengan figur lakilaki diperuntukkan bagi subjek laki-laki, sedangkan gambar dengan figur perempuan bagi subjek perempuan. Subjek diminta untuk memberikan rating ketertarikan terhadap setiap aktivitas pada gambar. Gambar 2 merupakan contoh aitem PGI versi gambar yang menunjukkan aktivitas minat sosial sebagai perwujudan dari aitem pernyataan "supervise children in a nursery".

Boerchi \& Magnano (2015) mengembangkan Iconographic Professional Interests Inventory (3IP) yang merupakan instrumen minat vokasional berbasis teori Holland. Instrumen tersebut terdiri atas 65 aitem yang menggambarkan figur yang sedang melakukan suatu pekerjaan. Penyajian gambar diikuti dengan nama profesi dari pekerjaan yang digambarkan pada bagian bawah dari gambar. Untuk setiap gambar, subjek diminta untuk memberikan rating ketertarikan antara 1-4. Gambar 3 menunjukkan 6 aitem dalam 3IP. Figur sengaja dibuat tanpa jenis kelamin dan ekspresi wajah untuk meminimalisasi pengaruh stereotip.

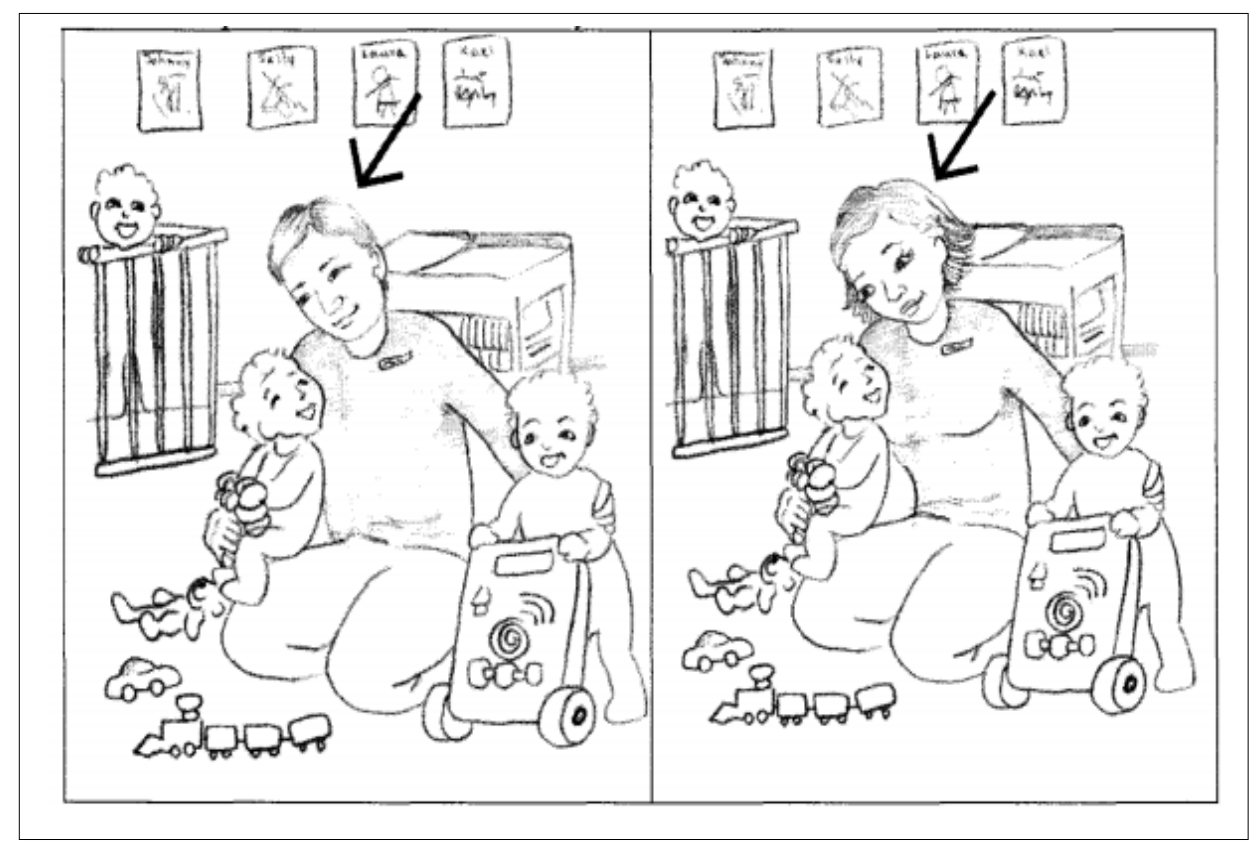

Gambar 2. Contoh aitem PGI format gambar dari aitem pernyataan "supervise children in a nursery". Diambil dari "A pictorial version of the RIASEC scales of the Personal Globe Inventory" oleh S. Enke, 2009, Disertasi, h.71 


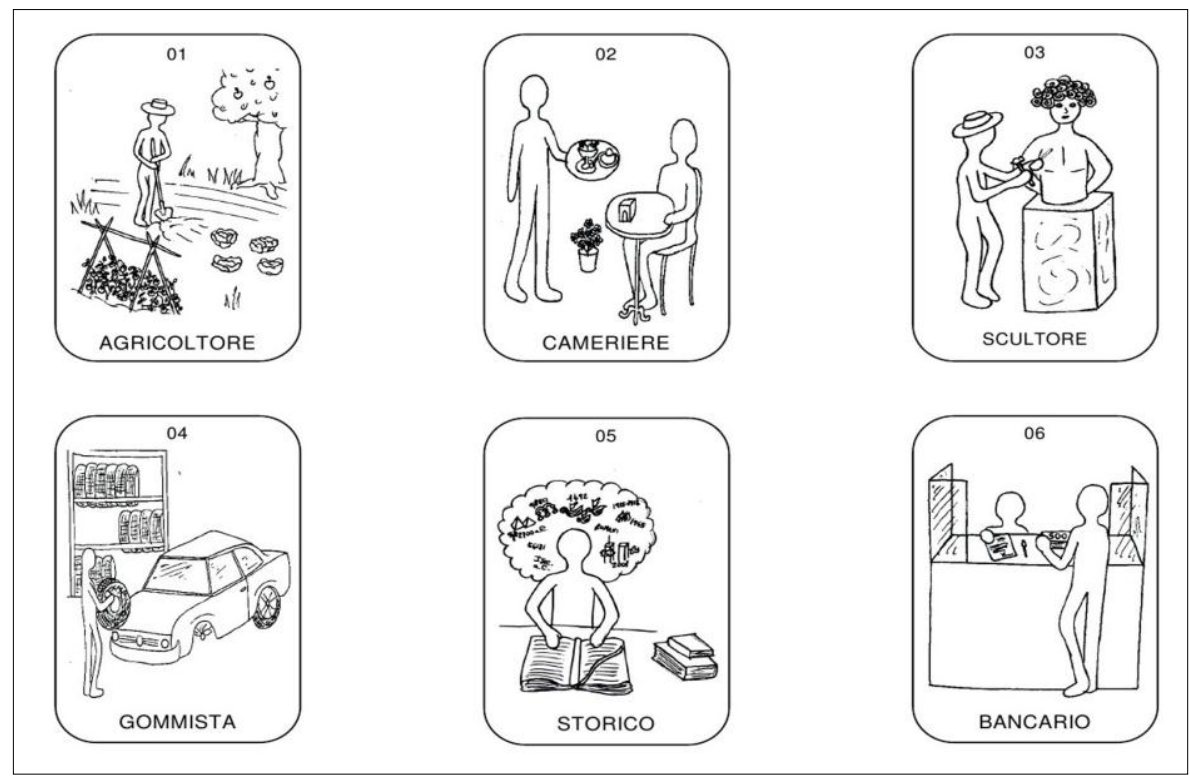

Gambar 3. Contoh 6 aitem 3IP. Diambil dari "Iconographic Professional Interests Inventory (3IP): A new validation study" oleh D. Boerchi, \& P. Magnano, 2015, Europe's Journal of Psychology, 1, h. 577.

Šverko, Babarović, \& Međugorac (2014) mengembangkan instrumen minat dengan nama Pictorial and Descriptive Interest Inventory (PDII). PDII terdiri atas 48 pekerjaan yang diwujudkan dalam bentuk foto individu yang mengerjakan aktivitas pekerjaan yang disertai dengan nama pekerjaan dan deskripsi singkat dari pekerjaan yang dituliskan pada bagian bawah foto. Pada setiap aitem, subjek diminta untuk memberikan rating ketertarikan serta kompetensi subjek dalam melakukan pekerjaan seperti yang tergambar. PDII tersedia dalam bentuk online melalui situs www.careerassessment.eu. Gambar 4 merupakan contoh aitem PDII dengan pekerjaan "Electronics technicians" yang merepresentasikan tipe minat Realistic.

\section{Kelebihan Stimulus Gambar}

Penggunaan stimulus berupa gambar memiliki kelebihan dibandingkan dengan stimulus berupa kata atau kalimat. Penggunaan stimulus gambar tidak mensyaratkan kemampuan membaca dari subjek (Šverko et al., 2014). Enke (2009) mengungkapkan bahwa kelemahan dari instrumen-instrumen minat Holland adalah kebergantungannya pada kemampuan subjek dalam membaca. Ini membuat instrumen-instrumen tersebut sulit untuk diakses oleh populasi yang mengalami kesulitan dalam membaca karena masalah apapun. Penggunaan stimulus gambar akan membuka jalan bagi populasi tersebut untuk bisa mengakses instrumen minat vokasional.

Kelebihan lain dari stimulus berupa gambar adalah dalam kemampuannya menggambarkan kondisi nyata. Stimulus berupa gambar dinilai lebih mendekati dunia nyata dibandingkan stimulus berupa pernyataan (Boerchi \& Magnano, 2015). Hal ini dikarenakan informasi mengenai lingkungan yang berkaitan dengan suatu pekerjaan juga turut tergambarkan (Šverko, et al., 2014). Aktivitas figur dalam gambar dapat terdukung oleh penggambaran lingkungan yang ada di sekitarnya. Aktivitas mengasuh anak misalnya akan digambarkan sebagai figur orang yang menggendong anak. Aktivitas tersebut akan dikuatkan dengan lingkungan berupa ruangan 


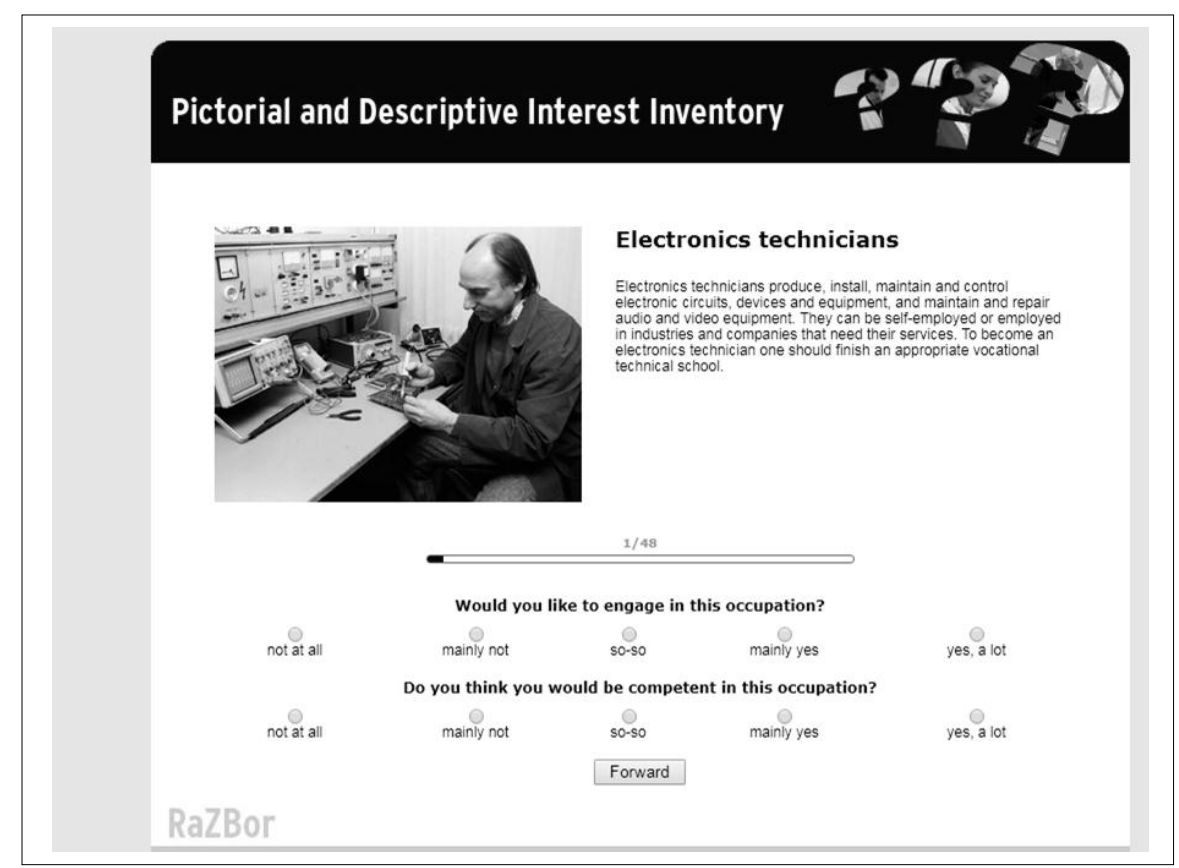

Gambar 4. Contoh Aitem PDII dengan Pekerjaan "Electronics technicians".

Diambil dari www.careerassessment.eu.

yang dipenuhi mainan anak. Instrumen minat umumnya diberikan pada individu yang berada pada masa remaja atau dewasa awal. Penyajian stimulus dalam bentuk gambar dinilai lebih menarik bagi kalangan tersebut (Šverko et al., 2014). Melalui penyajian instrumen minat yang menarik, kesungguhan subjek dalam mengerjakan instrumen diharapkan dapat meningkat sehingga hasil yang diperoleh pun benarbenar dapat mencerminkan diri subjek.

\section{Kelemahan Stimulus Gambar}

Penggunaan aitem berupa gambar memiliki beberapa kelemahan. Salah satunya adalah adanya kemungkinan gambar diinterpretasikan secara berbeda-beda oleh masingmasing individu (Šverko et al., 2014). Pemaknaan yang berbeda antar subjek tentunya akan memengaruhi respon yang diberikan oleh subjek.

Figur yang ditampilkan pada stimulus gambar juga dapat menjadi kendala dalam stimulus gambar. Individu dapat memilih suatu aitem terkait dengan karakteristik dari figur pada gambar misalnya dalam hal jenis kelamin. Subjek dimungkinkan akan mengidentifikasikan dirinya dengan karakter yang ada pada gambar dan cenderung memilih aktivitas yang digambarkan oleh karakter yang sama jenis kelamin dengan dirinya. Selain itu, penampilan fisik dari figur yang digambarkan, serta daya tarik dari latar yang dimunculkan dalam gambar dapat menimbulkan efek pada respon yang diberikan oleh subjek (Šverko et al., 2014).

Aitem berupa gambar memiliki keterbatasan dalam mengungkapkan kondisi yang sulit untuk diobservasi. Sverko (2014) mengungkapkan bahwa penggambaran minat Investigative, misalnya aktivitas melakukan penelitian terhadap suatu fenomena, lebih sulit dibandingkan dengan menggambarkan aktivitas minat Realistic seperti misalnya aktivitas dengan menggunakan objek, peralatan, serta mesin. Kondisi seperti ini dapat membuat aitem-aitem Realistic cenderung untuk lebih mudah dipahami oleh subjek dibandingkan dengan aitemaitem minat Investigative. 
Penggunaan stimulus gambar pada instrumen-instrumen minat yang ada umumnya masih disertai dengan informasi berupa kata atau kalimat. Meskipun stimulus utama berbentuk gambar, aitemaitem dalam 3IP dan PDII masih memasukkan informasi tertulis misalnya berupa nama pekerjaan. Hal ini memungkinkan individu dengan kemampuan membaca yang baik lebih diuntungkan dibandingkan dengan individu yang memiliki kesulitan dalam membaca. Beberapa gambar pada PGI versi gambar juga masih memunculkan kata-kata berbahasa Inggris (lihat Gambar 5). Enke (2009) menyarankan diperlukannya penelitian untuk mengetahui apakah gambar-gambar pada PGI versi gambar dapat diinterpretasikan secara tepat oleh populasi yang yang tidak bisa menggunakan informasi tambahan yang berupa tulisan.

\section{Langkah-langkah Pengembangan Stimulus Gambar}

Pengembangan inventori minat dengan stimulus berupa gambar dapat diawali dengan menyusun aitem-aitem berupa pernyataan. Aitem-aitem pernyataan tersebut tentunya disesuaikan dengan karakteristik minat sesuai dengan teori yang digunakan. Jika menggunakan teori Holland, maka karakteristik keenam minat Holland menjadi dasar dalam penyusunan aitem. Minat Realistic dapat diwujudkan misalnya dengan aktivitas menyervis motor, memperbaiki komputer, serta memperbaiki kelistrikan, sedangkan minat Investigative dengan aktivitas menyelidiki dengan mikroskop, mengobservasi perilaku anak, serta melakukan eksperimen kimia.

Aktivitas-aktivitas pernyataan yang telah dibuat kemudian diwujudkan dalam bentuk gambar. Aktivitas-aktivitas tersebut menjadi fokus dari setiap gambar. Latar belakang gambar perlu dibuat supaya dapat menguatkan aktivitas yang tergambar. Penampilan fisik serta cara berpakaian dari figur yang ditampilkan dalam gambar sebaiknya juga disesuaikan dengan kondisi kekinian.

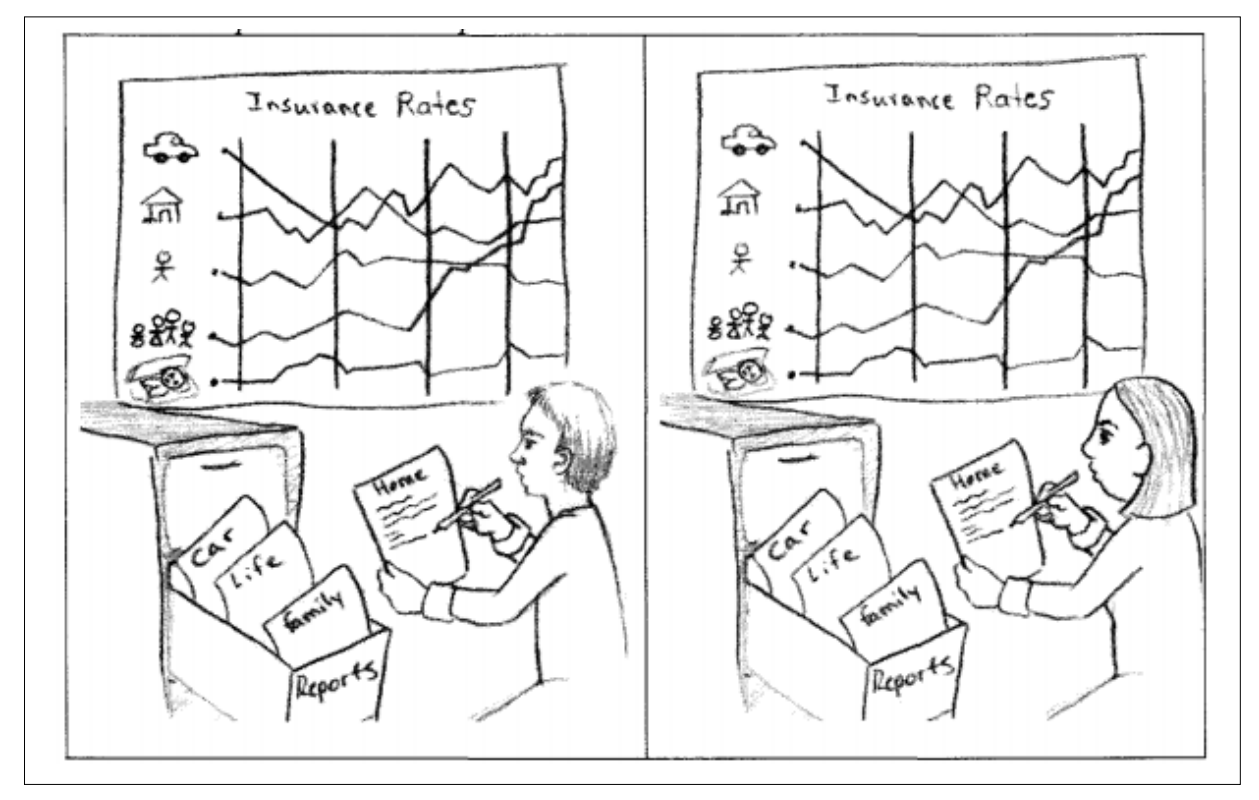

Gambar 5. Contoh Aitem PGI Format Gambar yang Menyertakan Informasi Tulisan.

Diambil dari "A pictorial version of the RIASEC scales of the Personal Globe Inventory" oleh S. Enke, 2009, Disertasi, h.61. 
Diperlukan pertimbangan serta kehatihatian dalam menggunakan warna pada stimulus gambar. Penggunaan warna pada gambar memang memiliki sisi positif karena dapat meningkatkan pengenalan individu terhadap suatu gambar (Dal Mas, Kühnel, Reichelt, Markowitsch, \& Piefke, 2013). Namun, penggunaan warna yang berbeda-beda dapat berpengaruh terhadap respon subjek. Hasil penelitian Yoto, Katsuura, Iwanaga, \& Shimomura (2007) menunjukkan bahwa berdasarkan evaluasi subjektif ditemukan adanya perbedaan perasaan ketika subjek diberi stimulus dengan warna merah dan biru, stimulus dengan warna merah memunculkan perasaan gembira dibandingkan stimulus warna biru. Perbedaan perasaan yang ditimbulkan dari warna dimungkinkan berpengaruh terhadap respon subjek terhadap gambar. Setiap individu juga memiliki warna favorit yang berbeda-beda. Jika secara kebetulan warna dari stimulus gambar yang disajikan kepada subjek merupakan warna favorit subjek, maka dimungkinkan subjek menyukai suatu gambar karena warnanya, bukan karena aktivitas pada gambar.

Pengontrolan dalam warna dapat dilakukan dengan membuat semua gambar hitam putih. Ini dilakukan sebagai usaha untuk menghindari adanya bias terhadap respon subjek karena pengaruh warna dari gambar. Dengan mengontrol warna pada gambar, perhatian subjek diharapkan hanya terfokus pada aktivitas pada gambar. Dengan demikian, ketika subjek menyatakan bahwa dirinya menyukai suatu gambar, maka hal itu benar-benar dikarenakan oleh minatnya terhadap aktivitas dalam gambar dan bukan karena hal yang lain.

Untuk menghindari bias yang terkait jenis kelamin, pengembangan stimulus berupa gambar perlu menyeimbangkan karakteristik figur dalam gambar (Šverko et al., 2014). Ini dapat diwujudkan dengan membuat gambar dengan figur laki-laki dan gambar dengan figur perempuan. Pada setiap gambar, aktivitas yang dilakukan figur dalam gambar dibuat sama. Aktivitas tersebut digambarkan baik oleh figur lakilaki maupun perempuan. Aitem dengan figur laki-laki diperuntukkan bagi subjek laki-laki, sedangkan aitem dengan figur perempuan diperuntukkan bagi subjek perempuan.

Contoh stimulus gambar yang dikembangkan oleh penulis terlihat pada Gambar 6 dan 7. Gambar 6 menunjukkan contoh aitem minat Realistic yang menggambarkan aktivitas menyervis motor. Gambar tersebut dibuat dengan warna hitam putih dan dibuat dalam versi figur laki-laki dan perempuan. Aktivitas menyervis motor pada gambar tersebut dikuatkan dengan latar kondisi bengkel. Gambar 7 menunjukkan contoh aitem minat Investigative yang menggambarkan aktivitas menyelidiki dengan miskroskop. Aktivitas tersebut dikuatkan dengan latar kondisi di laboratorium.

Untuk menguatkan kesesuaian gambar dengan karakteristik minat yang didasarkan pada teori Holland, validasi perlu dilakukan. Validasi isi dilakukan dengan memberikan gambar-gambar yang telah dibuat kepada para ahli sebagai penilai. Para ahli tersebut sebaiknya terdiri atas individu-individu yang memahami minat vokasional sebagai variabel psikologi yang hendak diukur (Furr, 2011), serta para ahli pengukuran/psikometri (Azwar, 2015). Para ahli diminta untuk memberikan penilaian sejauhmana gambar telah mencerminkan minat sesuai teori Holland. Hasil penilaian para ahli dapat dianalisis dengan formula Aiken's V atau Content Validity Ratio (Azwar, 2012). Gambar-gambar dengan indeks validitas isi yang tinggi dipilih sebagai aitem dalam inventori minat vokasional yang akan dikembangkan. 


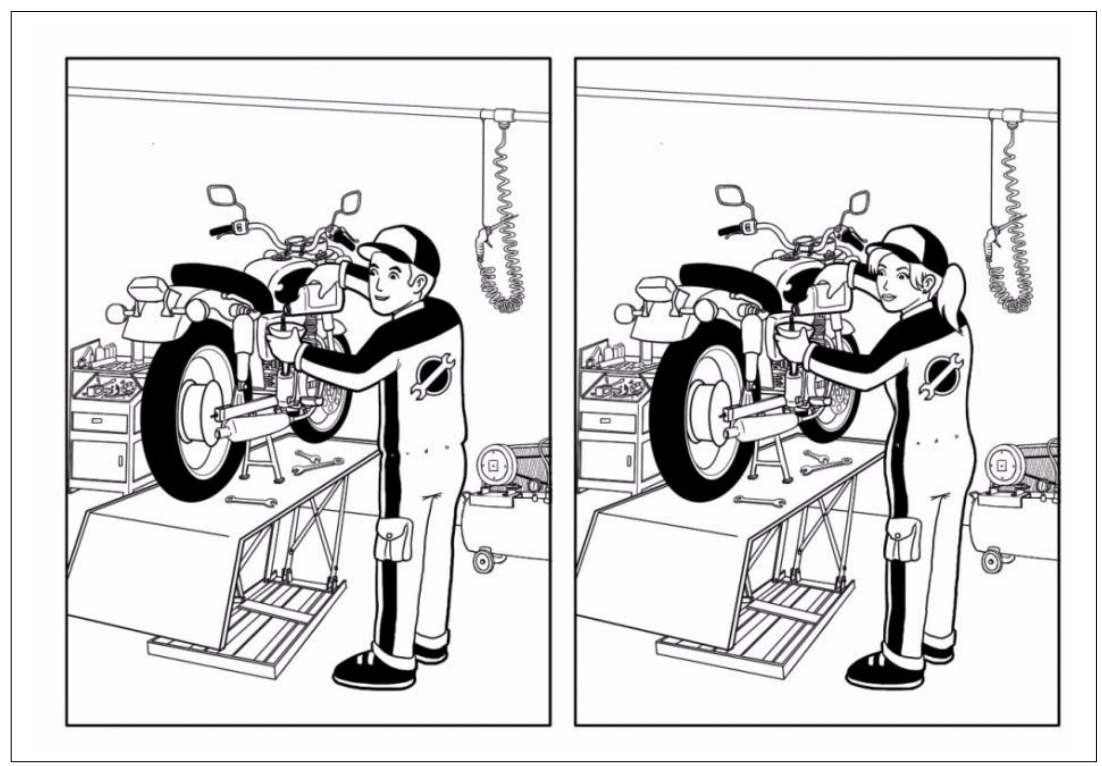

Gambar 6. Contoh Aitem Minat Realistic “Menyervis Motor” Versi Laki-Laki dan Perempuan

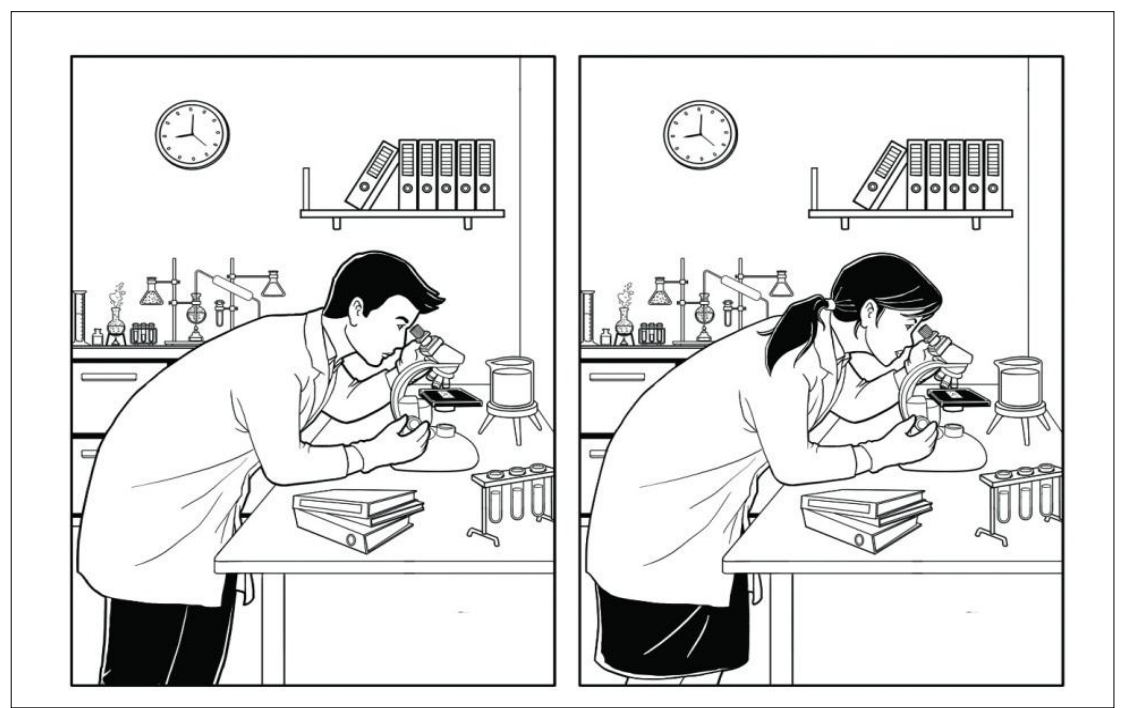

Gambar 7. Contoh Aitem Minat Investigative “Menyelidiki dengan Mikroskop” Versi Laki-Laki dan Perempuan.

Aitem-aitem gambar yang telah dibuat perlu diberikan kepada para pekerja atau yang dikenal sebagai para profesional. Holland (1985) telah menunjukkan berbagai pekerjaan yang dapat merepresentasikan masing-masing dari minat RIASEC. Contoh pekerjaan Realistic misalnya para insinyur otomotif, sipil, serta pertambangan, sedangkan contoh pekerjaan Investigative adalah ahli biologi, kimia, serta astronomi. Para profesional tersebut diminta untuk menilai sejauh mana kedekatan setiap gambar dengan pekerjaan mereka. Hal ini bertujuan untuk mengetahui sejauh mana gambar mampu merepresentasikan pekerjaan dari para profesional.

Data yang diperoleh dari para profesional dapat dibuat dalam bentuk tabel ekpektansi. Tabel ekspektansi dapat dipergunakan sebagai cara untuk melakukan validasi (Azwar, 2012). Melalui tabel ini, persentase para profesional dalam menilai kedekatan gambar-gambar dengan pekerjaan mereka dapat dihitung. Tabel ini 
sekaligus digunakan untuk mengetahui kelompok profesional yang memiliki persentase tertinggi dalam menilai suatu aitem. Sebagai contoh adalah para insinyur merupakan para profesional yang banyak bekerja dengan alat serta mesin, sehingga dikategorikan memiliki minat Realistic yang dominan. Oleh karena itu para insinyur diharapkan memberikan skor tinggi terhadap aitem-aitem Realistic. Semakin banyak insinyur yang memberikan skor tinggi pada aitem Realistic, semakin tinggi pula persentase kelompok profesional tersebut. Persentase yang telah diperoleh lalu dibandingkan dengan persentase kelompok profesional dari bidang pekerjaan yang lain.

Tabel 1 merupakan contoh tabel ekspektansi. Para profesional dikelompokkan berdasarkan pekerjaan ke dalam minat RIASEC Holland (1985). Dari para profesional tersebut dipilih profesional yang memberikan skor tinggi (misalnya skor 4 dan 5 jika rating skor antara 1-5) pada aitem R1, I1, A1, S1, E1, C1. Pada baris pertama terlihat bahwa persentase tertinggi pemilih aitem Conventional 1 (C1) adalah kelompok profesional dengan pekerjaan Conventional (80\%). Ini menunjukkan bahwa aitem $\mathrm{C} 1$ yang merepresentasikan minat Conventional memang paling dekat dengan pekerjaan para profesional di bidang Conventional. Persentase pada kelompokkelompok profesional dengan minat lain terlihat lebih rendah, seperti misalnya persentase kelompok profesional dengan pekerjaan Realistic adalah $10 \%$ dan persentase kelompok profesional dengan pekerjaan Investigative adalah 7\%.

Revisi terhadap gambar perlu dilakukan jika berdasarkan tabel ekspektansi banyak ditemukan aitem yang tidak sesuai dengan harapan. Aitem yang cenderung dipilih oleh semua kelompok profesional menunjukkan bahwa aktivitas pada aitem tersebut dekat dengan aktivitas keenam kelompok pekerjaan. Ini tentunya tidak diharapkan karena berarti aitem tersebut tidak dapat membedakan antar kelompok profesional. Aitem E1 pada Tabel 1 menjadi contoh kondisi ini. Meskipun persentase pemberi skor tertinggi adalah kelompok Enterprising (60\%), namun persentase kelompok profesional lain yang memberikan skor tinggi juga cukup tinggi seperti misalnya profesional dengan pekerjaan sosial (57\%) dan Conventional (55\%). Aitem dengan persentase tertinggi pada kelompok profesional yang tidak diharapkan juga perlu dikaji. Tabel 1 menunjukkan bahwa persentase kelompok pemberi skor tertinggi pada aitem S1 adalah kelompok profesional Enterprising (75\%), bukan kelompok profesional sosial seperti yang diharapkan. Hal ini menunjukkan bahwa aktivitas sosial yang tergambar pada aitem S1 justru lebih mendekati dengan pekerjaan para profesional di bidang Enterprising.

Tabel 1

Contoh Tabel Ekspektansi Minat berdasar Teori Holland

\begin{tabular}{ccccccc}
\hline Aitem & Profesional R & Profesional I & Profesional A & Profesional S & Profesional E & Profesional C \\
\hline C1 & $10 \%$ & $7 \%$ & $5 \%$ & $10 \%$ & $15 \%$ & $80 \%$ \\
E1 & $55 \%$ & $45 \%$ & $50 \%$ & $57 \%$ & $60 \%$ & $55 \%$ \\
S1 & $15 \%$ & $17 \%$ & $20 \%$ & $57 \%$ & $75 \%$ & $26 \%$ \\
A1 & $0 \%$ & $0 \%$ & $83 \%$ & $7 \%$ & $0 \%$ & $10 \%$ \\
I1 & $15 \%$ & $78 \%$ & $0 \%$ & $18 \%$ & $0 \%$ & $10 \%$ \\
R1 & $81 \%$ & $0 \%$ & $0 \%$ & $7 \%$ & $13 \%$ & $10 \%$ \\
\hline
\end{tabular}

Ket: $\mathrm{R}=$ Realistic, $\mathrm{I}=$ Investigative, $\mathrm{A}=$ Artistic, $\mathrm{S}=$ Social, $\mathrm{E}=$ Enterprising, $\mathrm{C}=$ Conventional 
Pra uji coba terhadap aitem-aitem perlu dilakukan untuk memastikan pemahaman subjek terhadap aitem (Azwar, 2015). Ini didasari oleh pandangan bahwa aitem gambar dapat dipahami secara berbedabeda oleh setiap subjek. Oleh karena itu, pra uji coba dimaksudkan untuk mengetahui sejauh mana perbedaan pemahaman para subjek terhadap setiap gambar. Jika subjek yang nantinya akan dikenai instrumen minat adalah remaja, maka subjek dalam pra uji coba juga harus dari kalangan remaja. Para remaja tersebut diminta untuk mengisi kuisioner yang berisi pertanyaan apa yang subjek pahami dari gambar beserta alasannya. Gambar-gambar yang tidak dipahami oleh sebagian besar subjek atau dipahami secara berbeda-beda oleh para subjek perlu untuk direvisi.

Aitem-aitem gambar yang telah lolos pada tahap pra uji coba siap untuk dikompilasikan menjadi instrumen minat vokasional. Dalam kondisi ini, format aitem dapat dibuat misalnya dengan menyajikan aitem gambar satu persatu atau secara berpasangan. Perbedaan format aitem tersebut tentu perlu mempertimbangkan format respon yang dikehendaki dalam pengembangan instrumen.

\section{Penutup}

Stimulus berupa gambar menjadi alternatif mengatasi kelemahan stimulus berupa pernyataan. Dibandingkan dengan stimulus pernyataan, penggunaan stimulus gambar tidak mensyaratkan kemampuan membaca dari subjek. Stimulus berupa gambar juga lebih mendekati kehidupan nyata. Namun demikian, stimulus gambar memiliki keterbatasan dalam mendeskripsikan kondisi yang sukar untuk diobservasi. Stimulus berupa gambar juga rawan menimbulkan interpretasi yang berbeda-beda dari para subjek. Untuk itu diperlukan kehati-hatian dalam mengembangkan stimulus berupa gambar sehingga setiap gambar dapat benar-benar merepresentasikan konstrak teoretis yang mendasarinya, serta tidak menimbulkan pemahaman yang berbedabeda dari para subjek penggunanya.

\section{Daftar Pustaka}

Artosandi, Y. S. R. (2016). Pengembangan instrumen minat vokasional berbasis tipologi Holland untuk eksplorasi karir siswa Sekolah Menengah Pertama (Disertasi Tidak Dipublikasikan). Program Pascasarjana Universitas Negeri Yogyakarta, Yogyakarta.

Azwar, S. (2012). Reliabilitas dan validitas. Yogyakarta: Pustaka Pelajar.

Azwar, S. (2015). Penyusunan skala psikologi. Yogyakarta: Pustaka Pelajar.

Becker, R. L. (1973). Vocational choice: An inventory approach. Education and Training of the Mentally Retarded, 8(3), 128-136.

Boerchi, D., \& Magnano, P. (2015). Iconographic Professional Interests Inventory (3IP): A new validation study. Europe's Journal of Psychology, 11(4), 571-596. doi: 10.5964/ejop.v11i4.927

Dal Mas, D. E., Kühnel, S., Reichelt, B., Markowitsch, H. J., \& Piefke, M. (2013). Influence of color on perceptual priming: A picture fragment completion paradigm. Procedia - Social and Behavioral Sciences, 82, 482-486. doi: 10.1016/ j.sbspro.2013.06.296

Dozier, V. C., Sampson, J. P., Lenz, J. G., Peterson, G. W., \& Reardon, R. C. (2015). The impact of the Self-Directed Search Form $\mathrm{R}$ internet version on counselor-free career exploration. Journal of Career Assessment, 23(2), 210224. doi: 10.1177/ 1069072714535020 
Enke, S. (2009). A pictorial version of the RIASEC scales of the Personal Globe Inventory. (Disertasi Tidak Dipublikasikan). Psychology Department Colorado State University, Colorado.

Foutch, H., McHugh, E. R., Bertoch, S. C., \& Reardon, R. C. (2014). Creating and using a database on Holland's theory and practical tools. Journal of Career Assessment, 22(1), 188-202. doi: 10.1177/ 1069072713492947

Furr, R. M. (2011). Scale construction and psychometrics for social and personality psychology. London: SAGE.

Geist, H. (1959). The Geist Picture Interest Inventory: General form: Male. Psychological Reports, 5(2), 413-438.

Goh, D. S., Lee, J. A., \& Yu, J. (2004). Factor Structure of the Strong Interest Inventory with a Chinese high school sample. The Journal of Psychology, 138(2), 171-184. doi: 10.3200/ JRLP.138.2.171184

Goh, D. S., \& Yu, J. (2001). Translation and validation of the Chinese Form of the strong interest inventory. Applied Psychology: An International Review, 50(2), 252-268.

Gregory, R. J. (2000). Psychological testing: History, principles, and applications (3rd ed.). Boston: Allyn \& Bacon, Inc.

Hansen, J.-I. C. (2011). Remembering John L. Holland, Ph.D. The Counseling Psychologist, 39(8), 1212-1217.

Holland, J. L. (1985). Making vocational choices: A theory of vocational personalities and work environments. USA: Prentice Hall, Inc.

Leung, S. A., \& Hou, Z. (2001). Concurrent validity of the 1994 Self-Directed Search for Chinese high school students in Hong Kong. Journal of Career Assessment, 9(3), 283-296.
Low, K. S. D., Yoon, M., Roberts, B. W., \& Rounds, J. (2005). The stability of vocational interests from early adolescence to middle adulthood: A quantitative review of longitudinal studies. Psychological Bulletin, 131(5), 713-737. doi: 10.1037/0033-2909. 131.5. 713

Miller, M. J. (2002). A longitudinal examination of a three-letter Holland code. Journal of Employment Counseling, 39(1), 43.

Nurcahyo, F. A., \& Azwar, S. (2008). Pengembangan skala minat untuk penjurusan akademis di Perguruan Tinggi. Humanitas, 5(2), 83-96.

Poitras, S.-C., Guay, F., \& Ratelle, C. F. (2012). Using the Self-Directed Search in research: Selecting a representative pool of items to measure vocational interests. Journal of Career Development, 39(2), 186207. doi: $10.1177 / 0894845310384593$

Ratri, W. D. (2016). Validasi Holland Self Directed Search (SDS) Form CP sebagai alat ukur minat karir. (Tesis Tidak Dipublikasikan). Fakultas Psikologi Universitas Gadjah Mada, Yogyakarta.

Šverko, I., Babarović, T., \& Međugorac, V. (2014). Pictorial assessment of interests: Development and evaluation of Pictorial and Descriptive Interest Inventory. Journal of Vocational Behavior, 84(3), 356366. doi: 10.1016/j.jvb.2014.02.008

Ting, S.-M. R. (2007). Comparing the Chinese Career Key and the SelfDirected Search with high school girls in Hong Kong. Journal of Career Development, 34(2), 192-209. doi: 10.1177/0894845307307474

Tracey, T. J. G. (2002). Personal Globe Inventory: Measurement of the spherical model of interests and competence beliefs. Journal of Vocational 
Behavior, 60(1), 113-172. doi: 10.1006/ jvbe. 2001. 1817

Van Iddekinge, C. H., Putka, D. J., \& Campbell, J. P. (2011). Reconsidering vocational interests for personnel selection: The validity of an interestbased selection test in relation to job knowledge, job performance, and continuance intentions. Journal of Applied Psychology, 96(1), 13-33. doi: 10.1037/ a0021193

Wetzel, E., Hell, B., \& Passler, K. (2012). Comparison of different test construc- tion strategies in the development of a gender-fair interest inventory using verbs. Journal of Career Assessment, 20(1), 88-104. doi: 10.1177/ 1069072711417166

Yoto, A., Katsuura, T., Iwanaga, K., \& Shimomura, Y. (2007). Effects of object color stimuli on human brain activities in perception and attention referred to EEG alpha band response. Journal of Physiological Anthropology, 26(3), 373379. doi: 10.2114/jpa2.26.373 